\author{
ANNA WINIARCZYK-RAŹNIAK \\ Uniwersytet Pedagogiczny w Krakowie, Polska \\ Pedagogical University of Krakow, Poland

\section{PIOTR RAŹNIAK} \\ Uniwersytet Pedagogiczny w Krakowie, Polska \\ Pedagogical University of Krakow, Poland
}

\title{
Magia Meksyku - Pueblos Mágicos w przestrzeni turystycznej kraju
}

\section{Magic of Mexico - Pueblos Mágicos in the Tourist Space of the Country}

\begin{abstract}
Streszczenie: Atrakcyjność turystyczna Meksyku opiera się na jego niezwykłej przyrodzie oraz przeszłości historycznej i bogactwie kulturowym, wyczuwalnym na każdym niemal kroku. Wpływa to na niezwykłą specyfikę terenów wiejskich, które w wielu przypadkach funkcjonują nadal w oparciu o tradycyjny sposób życia. Z kolei w miastach wyraźnie widoczny jest proces przenikania się kultury prehiszpańskiej i hiszpańskiej (kolonialnej). Na to nakłada się dodatkowo w największych miastach proces modernizacji, także w warstwie kulturowej i fizjonomicznej. Pomimo tego na terenie całego kraju znaleźć można nadal miejscowości, które do tej pory zachowały specyfikę i morfologię z czasów ich założenia. Od 2001 roku SECTUR (Secretaría de Turismo, 2019) administruje siedmioma programami regionalnymi, których zadaniem jest aktywizacja społeczności lokalnych (głównie w głębi kraju) poprzez m.in. prowadzenie wspólnej polityki marketingowej dotyczącej turystyki, a także dzięki stworzonym wspólnym planom rozwoju. Jednym z nich - szczególnym pod względem przestrzennym - jest program Pueblos Mágicos. Jako jedyny obejmuje on swoim zasięgiem cały kraj i zakłada współpracę między władzami na różnych szczeblach administracji państwowej oraz agendami rządowymi. Celem artykułu jest prezentacja programu Pueblos Mágicos, a także przedstawienie jego słabych i mocnych stron, wraz z propozycją dalszego jego funkcjonowania.
\end{abstract}

\begin{abstract}
The tourist attractiveness of Mexico is based on its unusual nature, history and cultural richness, which can be seen at almost every step. This affects the unusual specificity of rural areas, which in many cases still function based on the traditional way of life. In turn, in the cities, the process of permeating of the pre-Hispanic and Spanish (colonial) culture is clearly visible. On top of that, the process of modernisation is additionally imposed in the largest cities, also in the cultural and physiognomic layers. Despite this, throughout the country you can still find towns that have preserved the specificity and morphology of their founding. Since 2001, SECTUR (Secretaría de Turismo) administers seven regional programs whose task is to activate local communities (located mainly in the interior of the country) through, among others, conducting a common marketing policy on tourism, as well as through the creation of joint development plans. One of them special in terms of space - is the Pueblos Mágicos Program. As the only one, it covers the entire country and establishes cooperation between the authorities at various levels of state administration and government agencies. The aim of the article is to present the Pueblos Mágicos Program, as well as to present its strengths and weaknesses, along with the proposal to continue its operation.
\end{abstract}

Słowa kluczowe: Meksyk; program aktywizacji turystyki; Pueblo Mágico Keywords: Mexico; Pueblo Mágico; tourism activation program 
Otrzymano: 5 lutego 2019

Received: 5 February 2019

Zaakceptowano: 17 czerwca 2019

Accepted: 17 June 2019

\section{Sugerowana cytacja / Suggested citation:}

Winiarczyk-Raźniak, A., Raźniak, P. (2019). Magia Meksyku - Pueblos Mágicos w przestrzeni turystycznej kraju. Prace Komisji Geografii Przemysłu Polskiego Towarzystwa Geograficznego, 33(3), $112-126$. doi: 10.24917/20801653.333.8

\section{WSTĘP}

Atrakcyjność turystyczna Meksyku opiera się na jego niezwykłej przyrodzie oraz przeszłości historycznej i bogactwie kulturowym, wyczuwalnym na każdym niemal kroku. Buduje to również niezwykłą specyfikę terenów wiejskich, w wielu przypadkach nadal bazującą na tradycyjnym sposobie życia. Widoczne jest to również w szczególny sposób w miastach: zarówno w tych największych, jak i w niewielkich miejscowościach. W miastach wyraźnie widoczny jest proces przenikania się kultury prehiszpańskiej i hiszpańskiej (kolonialnej). Na to nakłada się dodatkowo w największych miastach proces modernizacji, także w warstwie kulturowej i fizjonomicznej.

Przez przeciętnego turystę Meksyk postrzegany jest przez pryzmat pięknych plaż, ciepłego morza i najbardziej znanych, monumentalnych zabytków, takich jak Chichén Itzá, Teotihuacan, Tulum, Monte Alban. W rzeczywistości jednak jest to zaledwie namiastka tego, co można zobaczyć w tym niezwykle rozległym i bardzo zróżnicowanym kraju. Urozmaicone krajobrazy naturalne i kulturowe na terenie Meksyku są różnorodne zarówno pod względem pochodzenia, historii, jak i tożsamości. W całym kraju znaleźć można nadal miejscowości, które do tej pory zachowały specyfikę i morfologię z czasów ich założenia.

Turystyka jest jednym z najważniejszych i najbardziej dynamicznych sektorów gospodarczych w Meksyku. Kolejne narodowe plany rozwoju Meksyku pozycjonują turystykę jako główny aspekt działalności gospodarczej. Dlatego też Ministerstwo Turystyki tworzy produkty turystyczne w celu pobudzenia rozwoju społecznego i gospodarczego, przy wykorzystaniu zasobów naturalnych i kulturowych. Zakładają one inwestycje finansowe, mające na celu pobudzenie działalności gospodarczej oraz tworzenie nowych miejsc pracy (Bustingorry, 2016; Rosas Jaco, Almeraya Quintero, Guajardo Hernández, 2017). Od lat siedemdziesiątych XX wieku w Meksyku (z większym lub mniejszym powodzeniem) realizowane są zatem rozmaite programy, których intencją jest ochrona jego bogatego dziedzictwa kulturowego. Wśród nich są programy, które mają za zadanie poszukiwanie nowych możliwości promocji i rozwoju obszarów o charakterze peryferyjnym. Mają one aktywizować rozwój turystyki i gospodarki na terenach, na których zachowane jest ich dziedzictwo historyczne oraz lokalna kultura, a mimo to ich istnienie nie jest znane szerszej grupie odbiorców. Turystyka w Meksyku stanowi znaczący wkład w gospodarkę kraju, zatem jest ona szczególnie istotna jako element wspierający słabo rozwinięte tereny wiejskie w obszarach peryferyjnych. Z założenia programy aktywizacji mają na celu zmniejszenie nierówności występujących pomiędzy zacofanymi gospodarczo terenami wiejskimi kraju a rozwiniętymi aglomeracjami miejskimi. Powstanie programów promujących rozwój turystyki jest 
też wynikiem koncentracji ruchu turystycznego na obszarach przybrzeżnych kraju, co powoduje potrzebę jego dywersyfikacji przestrzennej i produktowej.

Celem artykułu jest przedstawienie programu Pueblos Mágicos w kontekście jego słabych i mocnych stron. Dokonana zostanie także próba oceny tego programu oraz nakreślenie wyzwań stojących przed SECTUR (Secretaría de Turismo), które jest głównym administratorem programów aktywizujących turystykę w Meksyku.

\section{Program Pueblos Mágicos}

Od 2001 roku SECTUR nadzoruje siedem programów regionalnych, których zadaniem jest aktywizacja społeczności lokalnych (położonych głównie w głębi kraju) poprzez m.in. prowadzenie wspólnej polityki marketingowej dotyczącej turystyki, a także dzięki stworzonym wspólnym planom rozwoju. Programy regionalne działające obecnie w Meksyku to (rycina 1):

- Programa México Norte - Baja California, Chihuahua, Coahuila, Nuevo León, Sonora i Tamaulipas;

- Programa Mundo Maya - Campeche, Chiapas, Quintana Roo, Tabasco i Yucatán;

- Programa Ruta de los Dioses - Oaxaca, Puebla, Tlaxcala, Veracruz i Distrito Federal;

- Programa Tesoros Coloniales - Aguascalientes, Durango, Guanajuato, Michoacán, Querétaro, San Luis Potosí i Zacatecas;

- Programa En el Corazón de México - Distrito Federal, Estado de México, Guerrero, Hidalgo, Morelos i Tlaxcala;

- Centros de Playa - Baja California, Sonora, Quintana Roo, Veracruz i Tamaulipas;

- Programa Pueblos Mágicos - na terenie całego kraju.

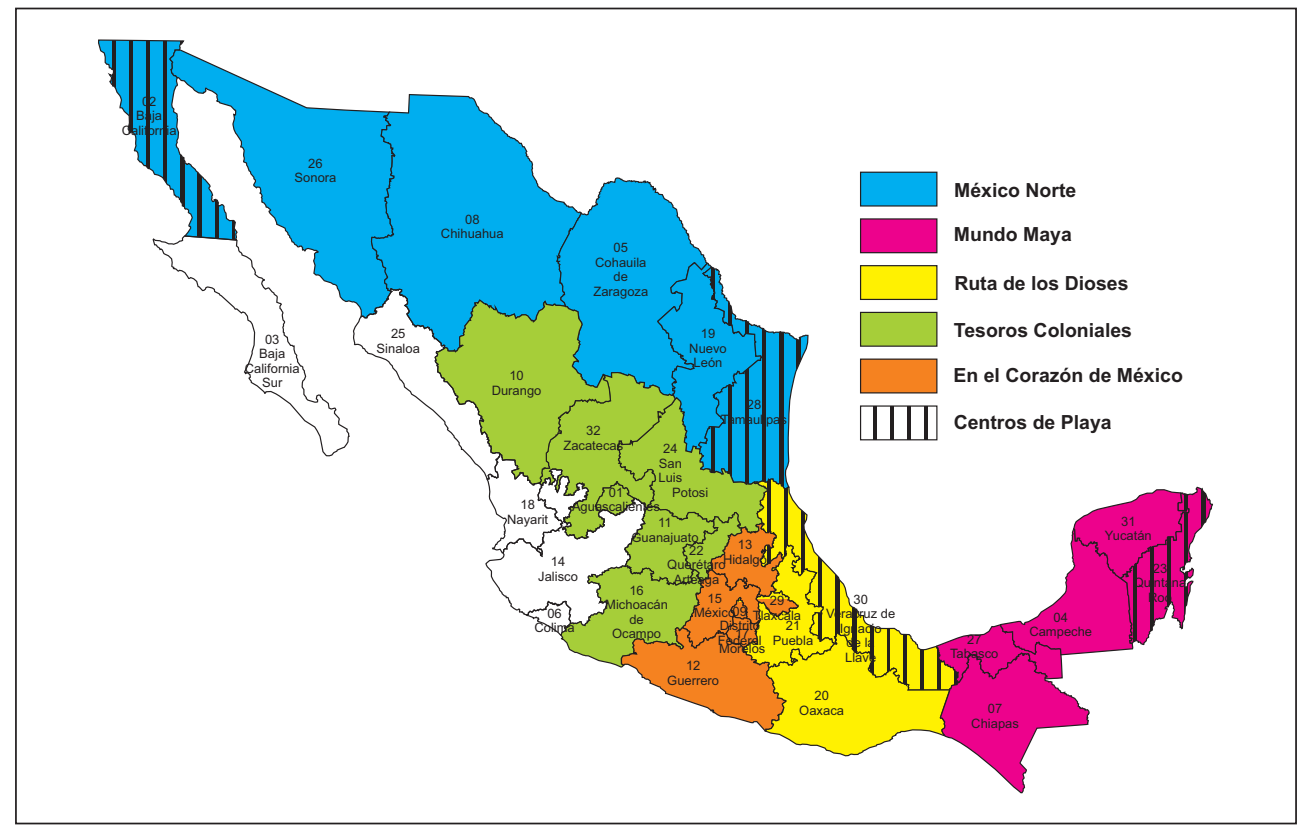

Źródło: opracowanie własne 
W tych programach zwraca się uwagę na rozwój różnych typów turystyki: wypoczynkowej, kulturowej, biznesowej itd. Mają one na celu poprawę funkcjonowania poszczególnych regionów turystycznych Meksyku oraz poprawę ich pozycji na rynku zarówno krajowym, jak i międzynarodowym. Zadaniem realizowanym w ramach omawianych regionów jest również wspólna promocja i tworzenie innowacyjnych produktów turystycznych w oparciu o badania rynkowe i techniki marketingowe. W niektórych programach zakładana jest również specjalizacja produktu na bazie specyfiki miejsca i dostępnych atrakcji turystycznych. Ważnym zadaniem, jakie w nich postawiono, jest podniesienie poziomu konkurencyjności i rentowności miejsc turystycznych oraz działających w branży firm.

Wśród tych programów szczególnym przypadkiem jest program Pueblos Mágicos (Magiczne miejscowości). Jako jedyny obejmuje swoim zasięgiem cały kraj i zakłada współpracę między władzami na różnych szczeblach administracji państwowej oraz agendami rządowymi. Program powstał w 2001 roku i ma na celu promocję unikalnych walorów turystycznych niewielkich miejscowości położonych na obszarach peryferyjnych, rozwój infrastruktury turystycznej w tych miejscach oraz stworzenie innowacyjnej oferty, zaspokajającej rosnące wśród turystów zapotrzebowanie na kulturę, umożliwiającej poznawanie lokalnych tradycji, promocję turystyki przygodowej oraz związanej z uprawianiem sportów ekstremalnych.

Program Pueblos Mágicos odgrywa w kraju szczególną rolę ze względu na swoje ukierunkowanie na rozwój lokalny (Pérez Corona, 2018). Początkowym celem projektu było ustrukturyzowanie oferty turystycznej na terenach peryferyjnych, przy wykorzystaniu historyczno-kulturowych walorów miejscowości. Lokalne społeczności, najczęściej położone w oddaleniu od najpopularniejszych w Meksyku destynacji turystycznych, charakteryzują się wyjątkowymi cechami, które postanowiono wykorzystać do stworzenia produktów turystycznych opartych m.in. na unikalnym rzemiośle, specyficznej gastronomii i lokalnych festiwalach. Dzięki położeniu daleko od ośrodków miejskich i dużych skupisk społeczności wiejskie dysponują różnorodnymi zasobami naturalnymi i kulturowymi. Założono zatem zwiększenie konkurencyjności tych miejscowości pod względem ich rozwoju jako destynacji związanych z uprawianiem m.in. turystyki przygodowej, sportów ekstremalnych, ekoturystyki, wędkarstwa sportowego (Bustingorry, 2016; Rodriguez Herrera, Pulido Fernández, Vargas Vásquez, Shaadi Rodriguez, 2018).

Program Pueblos Mágicos dąży do dywersyfikacji turystyki oraz wykorzystywania nowych możliwości i przestrzeni, które generują atrakcje związane z dziedzictwem materialnym i niematerialnym. Ma także na celu pozycjonowanie Meksyku jako międzynarodowej destynacji turystycznej (Bustingorry, 2016). Zgodnie z najnowszymi założeniami opublikowanymi przez SECTUR w 2017 roku, będącymi kontynuacją tez założycielskich program Pueblos Mágicos: „poszukuje sposobów na wykorzystanie naturalnych i (lub) kulturowych zasobów kraju, zwiększa zatrudnienie oraz zachęca do publicznych i prywatnych inwestycji w celu podniesienia poziomu dobrobytu ludności. Z tej perspektywy ogólnym celem programu jest: promowanie zrównoważonego rozwoju miejscowości mających cechy wyjątkowości i autentyczności przez wzmacnianie ich atrakcyjności marką wyjątkowości i prestiżu” (Guía para la Integración..., 2017).

Pueblo Mágico - Magiczna miejscowość - w założeniu ma charakteryzować się specyficznymi symbolicznymi atrybutami. Według Sekretariatu Turystyki Meksyku (SECTUR) Pueblo Mágico określane jest jako: „miejsce, które zachowało przed 
nowoczesnością swoje historyczne, kulturowe i naturalne dziedzictwo i manifestuje to w różnych przejawach przez swoje dziedzictwo materialne i niematerialne. Pueblo Mágico to miejscowość, która ma symboliczne cechy, legendy, historię, transcendentne fakty, życie codzienne, magię, emanującą na różnych płaszczyznach społeczno-kulturowych, które stwarzają obecnie doskonałe możliwości do wykorzystania ich w turystyce. Program Pueblos Mágicos przyczynia się do przewartościowania poglądów dotyczących społeczeństwa, które zawsze istniało w zbiorowej wyobraźni narodu jako całość i kreuje świeże i alternatywne możliwości dla odwiedzających je osób" (Guía para la Integración..., 2017; Pueblos Mágicos..., 2018).

Najważniejszymi oficjalnymi celami programu Pueblos Mágicos są:

1. Opracowanie komplementarnej i zdywersyfikowanej oferty turystycznej nakierowanej na rozwój obszarów peryferyjnych kraju, gdzie istnieje wiele szczególnych miejsc charakteryzujących się istotnymi z punktu widzenia rozwoju turystyki walorami historyczno-kulturowymi.

2. Rozwój i promocja lokalnego rękodzieła, świąt, tradycji i gastronomii.

3. Przygotowanie specyficznych produktów turystycznych, takich jak przygoda, sporty ekstremalne, ekoturystyka, wędkarstwo itp.

4. Waloryzacja i wsparcie dla istniejących atrakcji turystycznych w tych obszarach, będących nowymi i alternatywnymi rozwiązaniami dla rosnącego zainteresowania ze strony turystów zarówno krajowych, jak i zagranicznych.

Miejscowość funkcjonująca w programie powinna mieć zatem swoją „magię”, która emanuje i przejawia się w każdym z aspektów jego funkcjonowania. Definicja magii jest dość niejednoznaczna, podobnie w różny sposób można rozumieć, czy dane miejsce posiada symboliczne atrybuty, historię i codzienność. To powoduje, że stosunkowo łatwo można zbliżyć się do tej kategorii lub odejść od niej (Bustingorry, 2016). Niejednoznaczność terminologii stwarza więc szerokie możliwości dla działalności władz lokalnych, które dzięki odpowiedniej interpretacji mają możliwość wykorzystania zasobów, którymi dysponuje dana miejscowość. Z drugiej strony jednak stanowi przestrzeń dla pojawiania się różnego rodzaju nadużyć, co jest szczególnie niebezpieczne właśnie w Meksyku - kraju borykającym się na każdym kroku z problemem korupcji. Dlatego też niezwykle istotnymi aktorami w tym procesie stają się działacze polityczni i społeczni, reprezentujący miejscowości bądź pretendujące do uczestnictwa w programie, bądź też już w nim partycypujące. Początkowa koncepcja programu zakładała określone kryteria, które musiały spełniać miejscowości, aby zostać włączone do programu i uzyskać status Pueblo Mágico. Wśród tych wytycznych znajdowało się m.in. zaangażowanie społeczności i władz lokalnych, tworzenie i funkcjonowanie instrumentów planowania i regulacji prac, działalność aktywizująca rozwój miejscowości, stworzenie indywidualnej oferty atrakcji turystycznych i usług oraz rozwój lokalnych umiejętności (Rodríguez Herrera, Pulido Fernández, Vargas Vásquez, Shaadi Rodriguez, 2018).

Wymogi, jakie obecnie stawiane są miejscowościom pretendującym do grona Pueblos Mágicos, dotyczą między innymi liczby mieszkańców - powinna przekraczać 20 tys. osób. Nie mogą ponadto znajdować się dalej niż dwie godziny drogą lądową od istniejących już i funkcjonujących większych ośrodków recepcyjnych ruchu turystycznego, dzięki czemu uzupełniają one ofertę turystyczną prezentowaną przez duże miasta meksykańskie (Bustingorry, 2016; Núñez Camarena, 2016). Pozostałe zadania, jakie stawiane są nowym i istniejącym miejscowościom to: 
- przygotowanie komplementarnej i zróżnicowanej oferty turystycznej, opartej przede wszystkim na historyczno-kulturowych i naturalnych walorach miejscowości,

- wykorzystanie szczególnych cech miejscowości do kreowania nowych i udoskonalenia istniejących produktów turystycznych,

- wzrost wydatków na rzecz lokalnej społeczności,

- poprawa jakości oferowanych usług turystycznych,

- większa profesjonalność zatrudnionych pracowników,

- zachęcanie do nowych inwestycji,

- integracja działań prowadzonych przez miejscowości,

- reorganizacja działań w miejscowościach już znajdujących się w programie,

- promowanie rozwoju turystyki jako narzędzia dla zrównoważonego rozwoju w miejscowościach włączonych do programu (Guía para la Integración..., 2017). Władze miejscowości pretendującej do programu zobowiązane są do przedłożenia pełnej dokumentacji, obejmującej m.in. potwierdzenie utworzenia agendy administracyjnej zajmującej się turystyką, katalog dostawców usług turystycznych, inwentaryzację atrakcji turystycznych oraz plan rozwoju turystyki w miejscowości (Guía para la Integración..., 2017; Núñez Camarena, 2016). W zamian za spełnienie powyższych wymagań miejscowość otrzymuje przede wszystkim możliwość wykorzystywania logo i nazwy Pueblo Mágico, które stały się rozpoznawalną marką w ciągu kilkunastu lat funkcjonowania programu. Ponadto otrzymuje ona wsparcie finansowe od rządu federalnego z przeznaczeniem na poprawę funkcjonowania w zakresie infrastruktury, usług oraz wizerunku miasta. Fundusze przeznaczone mogą być m.in. na poprawę jakości lub rekultywację terenów turystycznych, tworzenie i rozwój produktów turystycznych, a także na doskonalenie jakości oferowanych usług (Bustingorry, 2016; Núñez Camarena, 2016).

\section{Pueblos Mágicos W PRZestrzeni Meksyku}

W 2018 roku do programu Pueblos Mágicos włączonych było 121 miejscowości. Są to niewielkie z reguły miasta, rozproszone na terenie całego niemal kraju (rycina 2) i charakteryzujące się bardzo zróżnicowanymi walorami: związanymi zarówno ze środowiskiem naturalnym, jak i dziedzictwem kulturowym, pochodzącym i z przeszłości prekolumbijskiej, i okresu kolonialnego. Zauważyć można koncentrację tych miejscowości w centrum kraju: prawie 60\% Pueblos Mágicos zlokalizowanych jest w jednym ze stanów znajdujących się w środkowej części Meksyku, pomiędzy Zatoką Meksykańską a wybrzeżem Pacyfiku (Núñez Camarena, 2016). Włączenie do programu nie jest jednak sytuacją stałą - miejscowości, które przestają z jakiegoś powodu spełniać warunki, są usuwane z listy. W 2008 roku z listy usunięto San Miguel de Allende (Guanajuato), które w tym czasie wpisane zostało na listę światowego dziedzictwa UNESCO. Z kolei trzy inne miejscowości straciły status Pueblo Mágico w 2009 roku ze względu na fakt, iż przestały spełniać założone w programie standardy. Dwa z usuniętych miast przywrócono ponownie na listę: w 2010 roku Tepoztlan (Morelos), a w 2012 roku Papantlę (Veracruz).

Rycina 3 przedstawia liczbę miejscowości włączanych do programu od początku jego funkcjonowania. Uwagę zwracają lata 2012 i 2015, kiedy to w programie znalazło się rekordowo dużo nowych miejscowości - odpowiednio 35 i 28. Najprawdopodobniej 
Rycina 2. Pueblos Mágicos w Meksyku

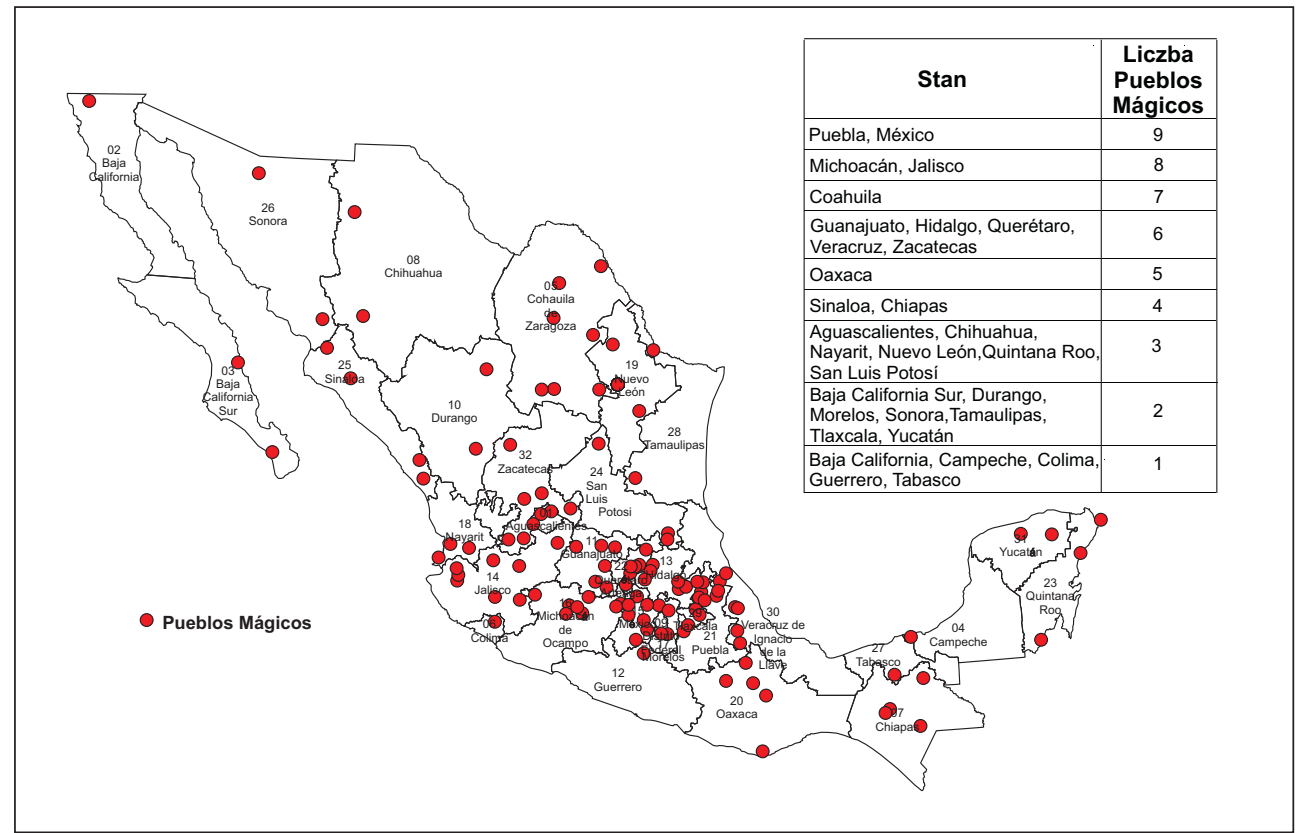

Źródło: opracowanie własne

na decyzji o przyłączeniu tak dużej liczby miejscowości w 2012 roku zaważyły względy polityczne. Włączanie większej liczby miast do programu w ciągu ostatnich lat prezydentury Felipego Calderona (2006-2012) wynikało z presji wywieranej przez polityków oraz burmistrzów miast, która skutkowała uzyskiwaniem środków finansowych na poziomie federalnym. Spotkało się to z silną krytyką, ponieważ uznano, że doszło do manipulacji przy nominacji kolejnych miast do programu (Armenta, 2014). Z kolei większa liczba miejscowości przyjętych do programu w 2015 roku była skutkiem wstrzymania nominacji dla nowych miejscowości w poprzednich dwóch latach.

Rycina 3. Liczba miejscowości włączanych do programu Pueblos Mágicos w latach 2001-2018

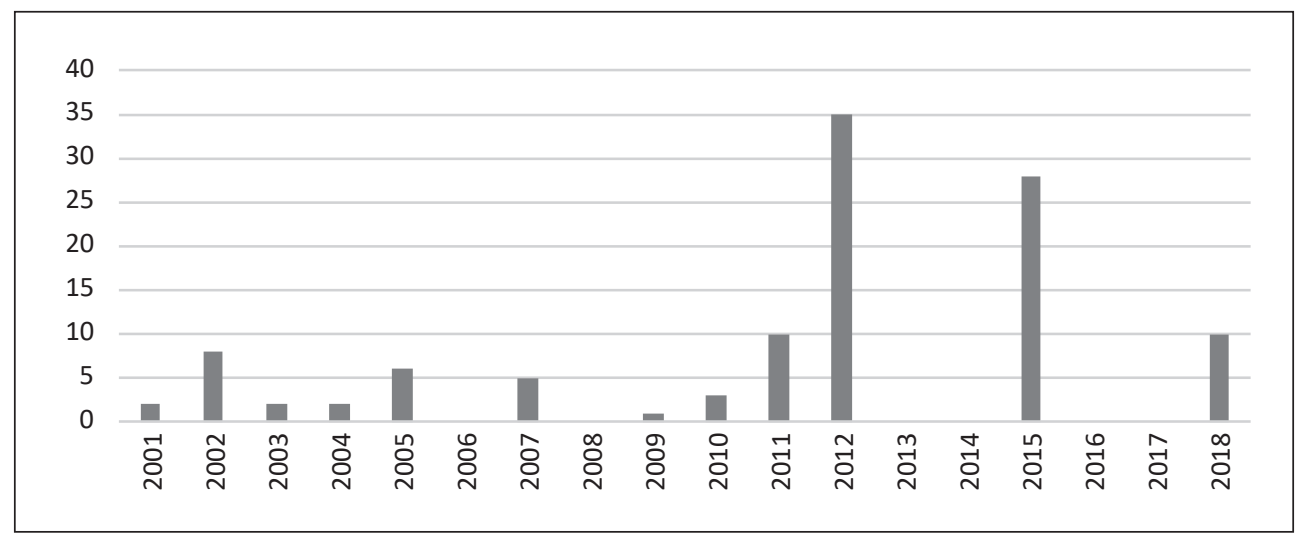

Źródło: opracowanie własne 


\section{MAlinAlco I TEQUila - PRZYKŁADY Pueblos MÁGicos}

Obecnie program Pueblos Mágicos obejmuje bardzo dużą grupę różnorodnych pod względem cech miejscowości. W czasie 17 lat trwania program ugruntował swoją markę, zaś logo jest powszechnie rozpoznawalne w kraju. Stał się on też upragnionym celem dla wielu miejscowości w obszarach peryferyjnych, które widzą w przynależności do niego swoją szansę na rozwój gospodarczy i społeczny. Literatura przedmiotu wskazuje jednak szereg problemów, których źródłem jest nie do końca kontrolowany intensywny rozwój turystyki w niewielkich miejscowościach.

W poprzednich latach przeprowadzano analizy skuteczności programu Pueblos Mágicos, bazując na wybranych przypadkach. Jeden z nich to gmina i miejscowość Malinalco, położona w południowo-zachodniej części stanu Meksyk. Zlokalizowana jest w odległości $60 \mathrm{~km}$ od miasta Toluca, w zasięgu oddziaływania jego obszaru metropolitalnego. Miejscowość Malinalco włączona została do programu w 2010 roku ze względu na swoje dziedzictwo związane z kulturami Tolteków, Teotihuacan, Matlatzinca i Azteków (fotografia 1). Szczególne znaczenie dla wyjątkowości tego miejsca miała działalność tych dwóch ostatnich kultur, po których pozostało do czasów współczesnych ważne stanowisko archeologiczne w Cuauhtinchan, z monolityczną piramidą świątynną, wyrzeźbioną bezpośrednio w zboczu górskim. Z okresu kolonialnego zachował się z kolei zespół klasztorny augustianów z XVI i XVIII wieku. Również z tego okresu pochodzi sanktuarium Señor de Chalma, jeden z najważniejszych ośrodków pielgrzymkowych w kraju.

Przeszłość historyczna oraz środowisko przyrodnicze Malinalco znajdują swoje odzwierciedlenie w wyjątkowej architekturze miejscowości. Doprowadziło to do znacznych inwestycji w duże projekty i prace infrastrukturalne: powstał tutaj klub golfowy, nowe drogi, hotele, restauracje, sklepy rzemieślnicze. Rozwinął się także znacząco

Fotografia 1. Malinalco - brama wjazdowa do miejscowości

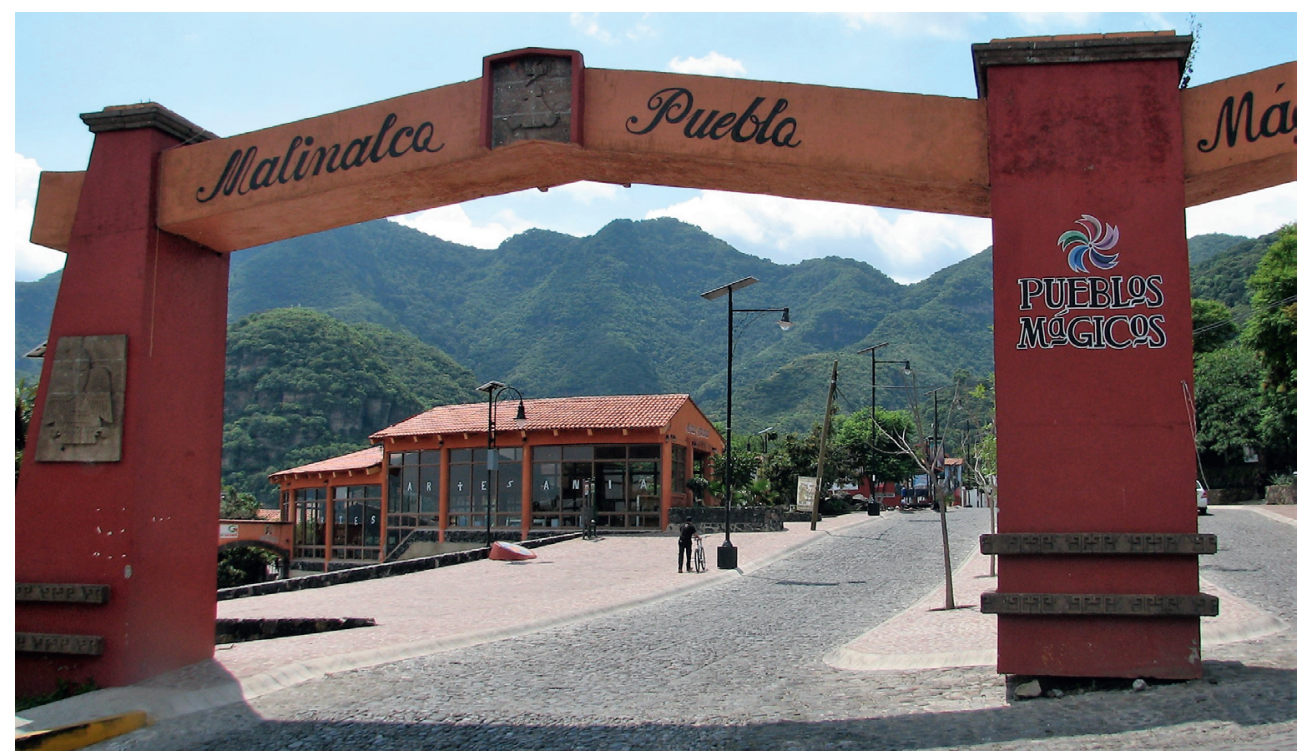

Źródło: fot. autorów 
handel nieruchomościami oraz działkami budowlanymi. Proces ten jednak, jak się ocenia, doprowadził do wielu konfliktów związanych z wykorzystaniem zasobów naturalnych (w szczególności wody) i kulturowych (Pérez Corona, 2018). Analizy omówione w literaturze identyfikują szereg problemów w tej miejscowości. Należą do nich przede wszystkim wzrost kosztów towarów i usług, problemy z segregacją i utylizacją odpadów, degradacja środowiska naturalnego. Pojawiły się również konflikty między władzami i inwestorami a lokalną społecznością, a także spory między ludnością zasiedziałą a nowymi mieszkańcami, którzy mają w Malinalco drugie domy. Poprawa warunków infrastrukturalnych jest jednym z czynników wpływających na poziom i jakość życia mieszkańców, a tym samym oddziałuje również na zwiększoną migrację do tych terenów (Winiarczyk-Raźniak, Raźniak, 2011; Raźniak, Winiarczyk-Raźniak, 2014). W przypadku omawianej miejscowości zwiększona liczba mieszkańców powoduje konflikty społeczne, które dotyczą użytkowania infrastruktury technicznej i drogowej, dostępu do zasobów ziemi i wody oraz transformacji kulturowej (Ramírez, Osorio, Nieto, Cortés, 2017; Pérez Corona, 2018).

Innym przykładem jest Tequila (fotografia 2), miejscowość położona w Obszarze Metropolitalnym Gudalajary - drugiego pod względem liczby mieszkańców miasta w Meksyku. Od wielu lat rozwój miasteczka podporządkowany jest produkcji napoju alkoholowego - tequili. Włączenie go do programu Pueblos Mágicos miało na celu rewitalizację centrum oraz jego promocję jako destynacji turystycznej, związanej z produkcją tego znanego na świecie alkoholu. Wśród wielu atrakcji, jakie można spotkać w Tequili, do najsłynniejszych należą: Hacienda i Destileria José Cuervo La Rojeña,

Fotografia 2. Centrum Tequili

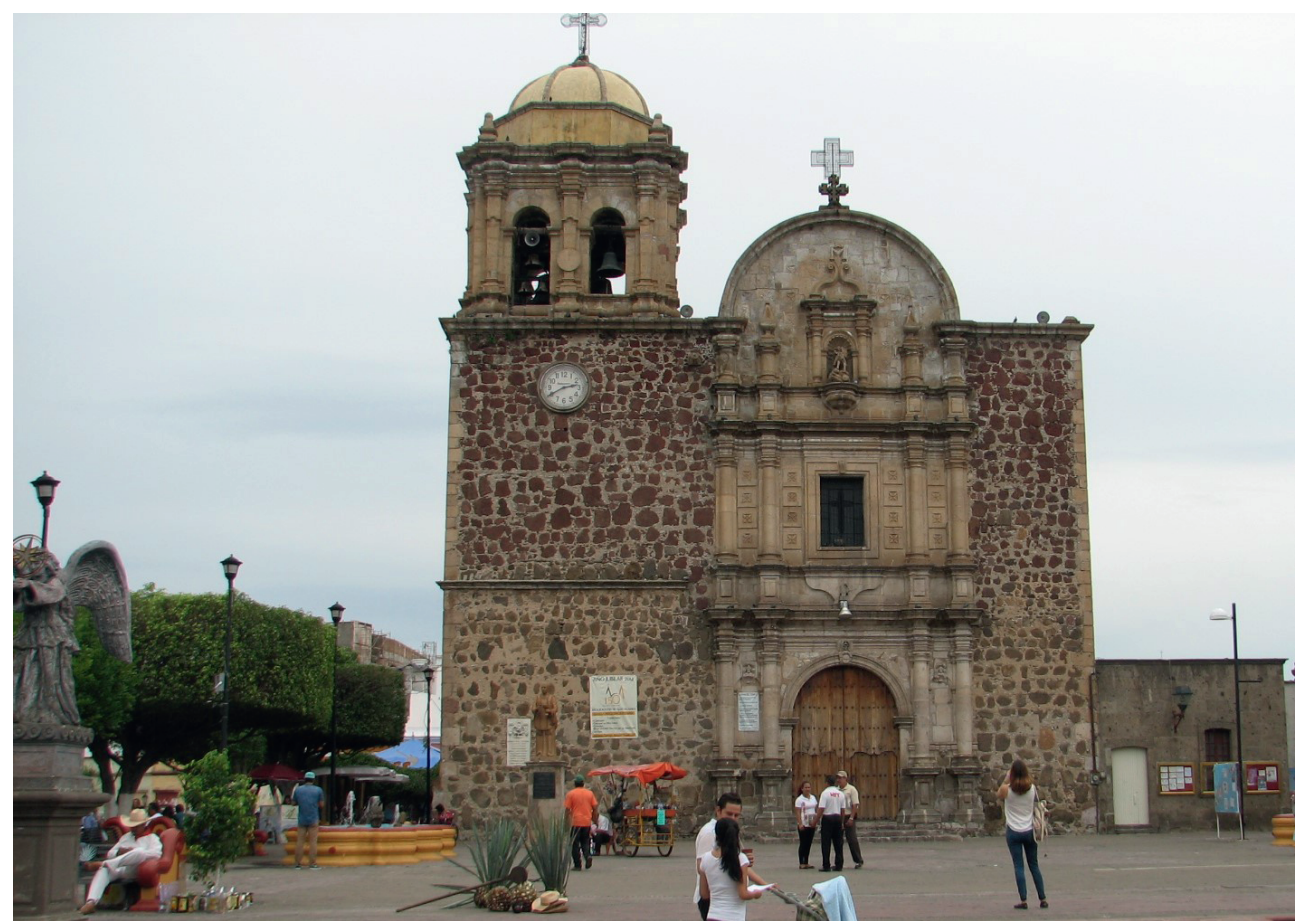

Źródło: fot. autorów 
Museo Nacional del Tequila, Tren Tequila Express oraz Parroquia de Santiago Apóstol i Santuario de la Santa Cruz. Miasto włączone zostało do programu Pueblo Mágico w 2003 roku, przede wszystkim dzięki staraniom niewielkiej grupy właścicieli najważniejszych firm z branży tequili, zainteresowanych wzięciem w nim udziału jako sposobu promowania wyjątkowego produktu (Hernández López, 2009). W Tequili istniała już uprzednio branża turystyczna, jednakże nie przynosiła zbyt wysokich dochodów. Dopiero bardziej zorganizowana, kompleksowa promocja spowodowała znaczny wzrost zainteresowania turystów tą destynacją.

Miasto liczy około 35 tys. mieszkańców, lecz zwraca uwagę dychotomia w podejmowanych inwestycjach w przestrzeni miasta. W związku z wejściem do programu w pierwszej kolejności dokonano rewitalizacji historycznego centrum, wyposażono je także w dwujęzyczne oznakowania. W kolejnych etapach rozbudowano bazę hotelową i gastronomiczną oraz poszerzono i wyremontowano główną drogę dojazdową do centrum. Jednakże kiedy J. Hernández López mówi o problemach miejscowości, stwierdza, że tereny peryferyjne kontrastują „(...) z magicznym centrum, które jest nie tylko bardziej widoczne i kolorowe, ale także ukrywa rzeczywiste warunki życia tradycyjnych ludzi (...)” (Hernández López, 2009: 56). Podczas przebudowy centrum nie brano pod uwagę zdania lokalnych społeczności, nie odbyły się też żadne konsultacje społeczne, zaś decydujący głos w tej sprawie mieli właściciele fabryk tequili, którzy zainicjowali proces włączenia miasta do programu.

Pozytywnym aspektem rozwoju turystyki związanej z wejściem do programu i nakierowanej na promocję tequili jest wzrost liczby firm towarzyszących temu procesowi. Pojawiły się wytwórnie lokalnych pamiątek, produkujące m.in. beczki, szklanki, kieliszki, butelki i inne pamiątkowe przedmioty związane z tequilą i agawą. Zwiększyła się w ostatnich latach liczba hoteli i restauracji, dających większe zatrudnienie. Więcej inwestycji w niewielkie firmy wynikało z prowadzonej przez władze polityki udzielania korzystnych mikrokredytów (Hernández López, 2009). Co prawda, wiele z tych miejsc pracy zajęły wykwalifikowane kadry mieszkające na co dzień w Guadalajarze, lecz zwiększenie inwestycji spowodowało również rozwój firm, np. budowlanych, istniejących w samej Tequili i zatrudniających mieszkańców miasta. Z drugiej strony jednakże miasto zmaga się z coraz większymi problemami związanymi z utylizacją odpadów, wynikającymi ze zwiększonej liczby turystów. Z kontrastami w rewitalizacji miasta wiąże się wiele konfliktów społecznych, wynikających z braku dialogu z lokalną społecznością, pogłębieniem polaryzacji społecznej, a także poczuciem niesprawiedliwości i odsunięcia mieszkańców od procesów decyzyjnych. W ostatecznym rozrachunku stwierdzić należy, że przyłączenie do programu w przypadku Tequili miało na celu przyciągnięcie turystów do miasta, a w szczególności do wielkich destylarni, a w dalszej kolejności chodziło o zachowanie specyficznego dziedzictwa tequili. Równocześnie jednak nie zostały wzięte pod uwagę potrzeby mieszkańców, co spowodowało wzmocnienie procesów wykluczenia społecznego w zakresie projektowania, realizacji oraz osiąganych dzięki programowi korzyści gospodarczych (Hernández López, 2009).

\section{KRYTYKA PROGRAMU}

Studia dotyczące programu Pueblos Mágicos podkreślają potencjał sektora usług turystycznych w zakresie wzrostu gospodarczego, tworzenia miejsc pracy, akumulacji kapitału i konkurencyjności. Jednakże miasta włączone w latach 2011 i 2012 okazały się 
nie być odpowiednio przygotowane do funkcjonowania w programie. W efekcie zbyt szybkiego włączania miast do programu i niejasnych kryteriów program zaczął tracić wiarygodność i dobrą markę. Konieczna stała się zatem weryfikacja wstępnych założeń oraz wprowadzenie większej kontroli.

Program zakłada rozwój infrastrukturalny miejscowości do niego włączonych dzięki celowemu finansowaniu. Jednakże w wielu miejscowościach dochodzi do polaryzacji przestrzennej tych inwestycji, które lokalizowane są głównie w miejscach najbardziej atrakcyjnych bądź planowanego rozwoju. Efektem tego są duże kontrasty w zainwestowaniu infrastrukturalnym w omawianych miejscowościach. Te różnice skutkują również konfliktami społecznymi, ponieważ mieszkańcy nie zgadzają się na odsuwanie dzielnic peryferyjnych od planów inwestowania w infrastrukturę (Jiménez Martínez, 2005; Shaadi Rodríguez, Pulido-Fernández, Rodríguez Herrera, 2017).

Wśród założeń programu ważnym elementem jest wsparcie dla rozwoju społeczności lokalnych przez wzrost wydatków na ich działalność. Udział lokalnej społeczności w tych projektach ma zasadnicze znaczenie, ponieważ działania, które zostaną przeprowadzone, będą realizowane przez mieszkańców i mają przynieść korzyści całej społeczności (Rosas Jaco, Almeraya Quintero, Guajardo Hernández, 2017). Jednakże planowana koordynacja działań pomiędzy różnymi agendami (federalnymi, stanowymi i miejskimi), która ma promować zrównoważoną turystykę i przynosić korzyści populacji przyjmującej, nie podlega odpowiedniej kontroli, która pozwoliłaby to zweryfikować. Często finansowanie lokalnych społeczności jest niewielkie lub żadne, zaś mieszkańcy otrzymują tylko zanieczyszczenia i śmieci pozostawione przez turystów. Duża część lokalnej populacji jest zatem wyłączona z inicjatyw i korzyści oferowanych przez program (Rojo Quintero, Llanes Guttierez, 2009; López Levi, 2018). W wielu przypadkach mieszkańcy nie są świadomi możliwych korzyści płynących z programu (López Levi, 2018). Równocześnie zaś ponoszą negatywne konsekwencje wynikające z większej liczby turystów, do których należy wzrost cen towarów i usług w tych miejscowościach. Skutkuje to polaryzacją oraz wykluczeniem społecznym i ekonomicznym (Pérez Corona, 2018; Pérez Ramírez, Antolín Espinoza, 2016).

Jedną z najbardziej widocznych konsekwencji programu jest ingerencja w wizerunek Pueblo Mágico. Miasto (a w szczególności te jego części, które mają przyciągać turystów), jest odpowiednio upiększane - miejsce jest dekorowane dla zadowolenia turysty. Problemem jednakże jest proces decyzyjny w tym zakresie - o doborze kolorów, stylu architektonicznego i zmianach decydują najczęściej krajowe lub regionalne instytucje nadzorujące dziedzictwo kulturowe, z niewielkim udziałem lokalnych urzędników i prawie żadnym mieszkańców. Dominuje najczęściej tendencja do naśladowania kolonialnej przeszłości, co niekiedy prowadzi do symulacji tradycji, a nie do przywracania świetności budynkom. Często też za obowiązujący uznaje się wygląd budynków czy całych miejscowości, charakterystyczny dla centralnego Meksyku, który nie przystaje jednak do rzeczywistej fizjonomii miejscowości w innych częściach kraju. Widoczne są również zmiany w użytkowaniu ziemi wskutek tworzenia nowych przestrzeni turystycznych (restauracje, kluby, hotele, parki rozrywki), powodujące nieodwracalny zanik tradycyjnej tożsamości przekształcanych miejsc. Chęć poprawy wizerunku miasta spowodowała również wyprowadzenie niektórych funkcji na tereny peryferyjne. Przykładem tego jest przenoszenie placów targowych lub eksmisja ulicznych sprzedawców z placów miejskich (Hérnandez López, 2009; López Levi, 2018). 
Bardzo trudnym problemem są zmiany, jakim ulega lokalne dziedzictwo kulturowe wskutek intensyfikacji ruchu turystycznego. Program zakłada m.in. promocję tego aspektu, co jednak często wiąże się z kreowaniem całkiem nowego obrazu kulturowego tego miejsca. Jest to efektem konsumpcyjnego podejścia do promocji turystyki w miastach Pueblos Mágicos, bez refleksji nad prawdziwą tożsamością tych miejscowości. Historia tych miejsc jest zmieniana bądź wymyślana na nowo, uatrakcyjniana przez dodanie np. opowieści o duchach, niesamowitych wydarzeniach historycznych lub tragicznych historiach miłosnych. „Poprawiane” są również tańce i kostiumy, coraz mniej mające wspólnego z rzeczywistym dziedzictwem regionu, „(...) przekształcając tożsamość i pamięć w spektakl dla konsumpcji coraz bardziej zglobalizowanej masy (...)" (Delgado, 2007: 96). W wielu przypadkach dochodzi do zamiany dziedzictwa kulturowego w produkt turystyczny, co prowadzi w wielu przypadkach do trywializacji tradycji, obyczajów, obrzędów, a także tradycyjnych zajęć i stylu życia (Bustingorry, 2016).

Kolejną kwestią wynikającą z intensywnego rozwoju turystyki i promocji miejscowości jest gentryfikacja. Wzrost atrakcyjności tych miejsc skutkuje przyciąganiem do nich nowych mieszkańców, wykupywaniem historycznych budynków w centrach miejscowości oraz migracjami ludności zasiedziałej na tereny peryferyjne (Rojo Quintero, Llanes Gutiérez, 2009). Efektem wzrostu atrakcyjności tych terenów i wykupywania ich przez nowych mieszkańców jest wzrost cen nieruchomości (Pérez Corona, 2018).

Rozwój turystyki w obszarach peryferyjnych Meksyku dokonuje się w oparciu m.in. o atrakcyjność naturalnego krajobrazu. Niestety, nowe inwestycje związane z turystyką nie są poddawane kontroli, zarówno pod względem lokalizacji, jak i rodzaju działalności. Chociaż w programie zwraca się uwagę na zrównoważony rozwój, wskutek rozbieżnych wizji dotyczących wykorzystania lokalnych zasobów jest on mylnie rozumiany jako wykorzystanie krajobrazu w celu przyciągnięcia turystów (Perez Corona, 2018). Następstwem tego w środku parków przyrody, jak w przypadku Pueblo Mágico Mineral del Chico w Hidalgo lub Valle de Bravo w stanie Meksyk, tworzone są parki linowe, tereny dla quadów oraz miejsca wspinaczkowe (López Levi, 2018).

\section{WNIOSKI KOŃCOWE}

Przegląd dostępnej literatury przedmiotu, raportów oraz źródeł internetowych wskazuje, że program Pueblos Mágicos niewątpliwie jest zjawiskiem bardzo złożonym. Pierwotne jego założenia były pozytywne i miały przynieść wiele korzystnych efektów. Jednakże brak od samego początku jasno zdefiniowanych kryteriów oraz kontroli stopnia realizacji założeń spowodował wystąpienie szeregu niekorzystnych zjawisk.

Program aktywizacji turystyki w obszarach peryferyjnych miał za zadanie przyczynić się do rozwoju lokalnego. Zwiększone finansowanie infrastruktury, promocji oraz rewitalizacji poprawiło wizerunek wielu miejscowości w programie. Spowodowało również napływ inwestycji, które pociągnęły za sobą wzrost liczby miejsc pracy, powstawanie nowych firm i zwiększenie zysków tych wcześniej istniejących. Dzięki programowi wiele miejsc zyskało też wsparcie w postaci odpowiedniej reklamy, co wskazało szerszej grupie odbiorców na możliwości odkrycia nowych, nieoczywistych destynacji turystycznych.

Zdaniem autorów rzeczywiste działania spowodowały jednak równocześnie wiele niekorzystnych skutków. Należą do nich pogłębianie się polaryzacji społecznej, kontrastów w warunkach życia społeczności lokalnych, niekontrolowana eksploatacja 
zasobów naturalnych i kulturowych. Wiele miejscowości funkcjonujących w programie jest zarządzanych bez odpowiednich planów i strategii, które w założeniu miały zapewnić harmonię działań. Brak tych oficjalnych i zatwierdzonych administracyjnie narzędzi w rzeczywistości skutkuje wieloma konfliktami, bazującymi na sprzecznych interesach aktorów uczestniczących w działaniu programu.

Chociaż turystyka oznacza możliwość rozwoju gospodarczego, wiąże się z tym duże ryzyko, jeśli nie zostanie zachowane dziedzictwo kulturowe (materialne i niematerialne). Dziedzictwo to w wielu przypadkach traktowane jest jako zwykły artykuł konsumpcyjny, co oznacza, że coraz częściej postrzegane jest jako towar, w efekcie czego dochodzi do "disneylandyzacji” wielu miejsc atrakcyjnych z punktu widzenia turystyki kulturowej. Ważną kwestią jest również szacunek i troska o środowisko natural$n e, w$ wielu miejscach silnie degradowane wskutek intensywnego i szybkiego rozwoju turystyki w obszarach inwestowanych w ramach różnych programów wspierających. Turystyka w programach aktywizacji obszarów peryferyjnych musi być ponadto elementem wsparcia dla lokalnych społeczności, zatem powinna skutkować korzyściami gospodarczymi i przyczynić się do poprawy jakości ich życia.

Program Pueblos Mágicos wymaga solidnego planu zarządzania, który zapewniałby prawidłowe funkcjonowanie systemu, a także niezbędnego, dogłębnego przeglądu dotychczasowych zasad (Lopez Levi, 2018). Należy zwrócić w nim uwagę na odpowiednie normy i zasady, uniemożliwiające spekulacje gruntami oraz wymuszające rzeczywiste, regularne i solidne prowadzenie konsultacji z lokalnymi społecznościami. Ułatwi to bieżącą identyfikację pojawiających się problemów lokalnych i podjęcie ewentualnych działań ograniczających niekorzystny wpływ intensyfikacji ruchu turystycznego na mieszkańców, dziedzictwo kulturowe oraz środowisko naturalne. Powinien być ponadto wdrożony system regularnej kontroli działania tego programu, a także bieżąca weryfikacja stopnia realizacji założeń programu Pueblos Mágicos.

Według autorów niniejszego opracowania korzystnym działaniem, zarówno dla funkcjonowania programu, jak i dla samych miejscowości mogłoby być częściowo zindywidualizowane podejście do poszczególnych Pueblos Mágicos na bazie rzetelnie przeprowadzonych konsultacji społecznych. Należałoby w nim obiektywnie określić ewentualne kierunki rozwoju każdego z nich w oparciu o wyjątkowe i specyficzne cechy tych miejscowości, a także ich możliwości i problemy. Opracowane na tej podstawie strategie rozwoju turystyki miałyby największą szansę na realizację przy równoczesnej minimalizacji negatywnych skutków.

\section{Literatura}

\section{References}

Armenta, G. (2014) (2018, 16 listopada). Cuál es la situación real de los Pueblos Mágicos. Forbes México. Pozyskano z http://www.forbes.com.mx/develan-misteriosde-los-pueblosMágicos/

Bustingorry, F. (2016). Pueblos Mágicos. El proyecto de patrimonialización de localidades mexicanas para promover el turismo. Ingeniería, Tecnología y Ciencias Aplicadas, 1, 49-53.

Delgado, M. (2007). Ciudades sin ciudad. La tematización "cultural" de los centros urbanos. W: D. Lagunas (red.). Antropología y Turismo. Claves culturales y disciplinares. Pachuca de Soto: Universidad Autónoma del Estado de Hidalgo, 91-108.

Guía para la Integración documental Pueblos Mágicos (2017) (2018, 24 października). SECTUR. Pozyskano z https://www.gob.mx/cms/uploads/attachment/file/273030/Gui_a_2017_de_ Incorporacio_n_2017.pdf 
Hernández López, J. (2009). Tequila: centro mágico, pueblo tradicional. ¿patrimonialización o privatización? Andamios, 6(12), 41-67.

Jiménez Martínez, A.J. (2005). Desarrollo turístico y Sustentabilidad. El caso de México. México: Universidad Intercontinental, 191.

López Levi L. (2018). Las territorialidades del turismo: el caso de los Pueblos Mágicos en México. Ateliê Geográfico-Goiânia-GO, 12(1), 6-24.

Núñez Camarena, G.M. (2016). Los pueblos mágicos de México: mecanismo de la SECTUR para poner en valor el territorio. W: Seminario Internacional de Investigación en Urbanismo. Departament d'Urbanisme i Ordenació del Territori. Universitat Politècnica de Catalunya, Barcelona: DUOT.

Pérez Corona, J. (2018). Desarollo local y turismo en México. Pueblos Mágicos en regiones metropolitanas. W: Desarollo regional sustenable y turismo. México: Universidad Nacional Autónoma de México y Asociación Mexicana de Ciencias para el Desarrollo Regional.

Pérez Ramírez, C.A., Antolín Espinosa, D.I. (2016). Programa Pueblos Mágicos y desarrollo local: actores, dimensiones y perspectivas en El Oro, México. Estudios Sociales, 25(47), 219-243.

Pueblos Mágicos, herencia que impulsan Turismo (2018, 20 listopada). Secretaría de Turismo, Pozyskano z https://www.gob.mx/sectur/articulos/pueblos-magicos-herencia-que-impulsan-turismo?idiom=es

Ramírez, I., Osorio, M., Nieto, C., Cortés, I. (2017). ¿Así son, así se imaginan ellos, o así los imaginamos? Reflexiones sobre las transformaciones socioterritoriales del turismo residencial en Malinalco, México. Revista EURE - Revista De Estudios Urbano Regionales, 43(129), 143-164.

Raźniak, P., Winiarczyk-Raźniak, A. (2014). Influence of the societal security level on population migrations in Poland. Procedia - Social and Behavioral Sciences, 120, 2-12.

Rodríguez Herrera, I.M., Pulido Fernández, J.I., Vargas Vásquez, A., Shaadi Rodriguez, R.M. (2018). Dinámica relacional en los Pueblos Mágicos de México. Estudio de las implicaciones de la política turística a partir del análisis de redes. Turismo y Sociedad, XXII, 85-104. doi: 10.18601/01207555.n22.05

Rojo Quintero, S., Llanes Gutiérrez, R.A. (2009). Patrimonio y turismo: el caso del Programa Pueblos Mágicos. Topofilia. Revista de Arquitectura, Urbanismo y Ciencias Sociales, Centro de Estudios de América del Norte, El Colegio de Sonora, I(3), 1-15.

Rosas Jaco, M.I., Almeraya Quintero, S.X., Guajardo Hernández, L.G. (2017). Los comités Pueblos Mágicos y el desarollo turístico: Tepotzotlán y El Oro. Agricultura, Sociedad y Desarollo, 14, 105-123.

Secretaría de Turismo, SECTUR (2019, 2 lutego). Pozyskano z http://www.sectur.gob.mx/programas/programas-regionales/

Shaadi Rodríguez, R.M.A., Pulido-Fernández, J.I., Rodríguez Herrera, I.M. (2017). El producto turístico en los Pueblos Mágicos de México. Un análisis crítico de sus componentes. Revista de Estudios Regionales, 108, 125-163.

Winiarczyk-Raźniak, A., Raźniak, P. (2011). Regional differences In the standard of living in Poland (based on selected indices). Procedia - Social and Behavioral Sciences, 19, 31-36.

Anna Winiarczyk-Raźniak, dr, Uniwersytet Pedagogiczny w Krakowie, Wydział Geograficzno-Biologiczny, Instytut Geografii, Zakład Geografii Społeczno-Ekonomicznej. Do jej zainteresowań badawczych należy geografia społeczna Ameryki Łacińskiej, w szczególności zróżnicowanie etniczno-kulturowe, turystyka w Ameryce Łacińskiej oraz hierarchie miast światowych i funkcje kontrolno-zarządcze miast kreowane przez korporacje.

Anna Winiarczyk-Raźniak, PhD, Pedagogical University of Krakow, Faculty of Geography and Biology, Institute of Geography, Department of Socio-Economic Geography. Her research interests include social geography of Latin American countries, especially ethnic and cultural composition, tourism in Latin America and hierarchies of world cities and command and control functions of cities created by large corporations.

ORCID: 0000-0002-5276-5297

\section{Adres/address:}

Uniwersytet Pedagogiczny w Krakowie

Instytut Geografii

Zakład Geografii Społeczno-Ekonomicznej

ul. Podchorążych 2, 30-084 Kraków, Polska

e-mail: anna.winiarczyk-razniak@up.krakow.pl 
Piotr Raźniak, dr, Uniwersytet Pedagogiczny w Krakowie, Wydział Geograficzno-Biologiczny, Instytut Geografii, Zakład Geografii Społeczno-Ekonomicznej. Do jego zainteresowań badawczych należą problemy gospodarcze miast, hierarchie miast światowych, problemy funkcjonowania obszarów metropolitalnych oraz funkcje kontrolno-zarządcze miast kreowane przez korporacje.

Piotr Raźniak, PhD, Pedagogical University of Krakow, Faculty of Geography and Biology, Institute of Geography, Department of Socio-Economic Geography. His research interests include corporations, hierarchies of world cities, problems of functioning of metropolitan areas, spatial structure of corporations and command and control functions of cities created by large corporations.

ORCID: 0000-0001-9757-7022

\section{Adres/address:}

Uniwersytet Pedagogiczny w Krakowie Instytut Geografii

Zakład Geografii Społeczno-Ekonomicznej

ul. Podchorążych 2, 30-084 Kraków, Polska

e-mail: piotr.razniak@up.krakow.pl 